\title{
PEMBELAJARAN ONLINE BERBASIS PROYEK PADA MATA PELAJARAN BAHASA INGGRIS DITENGAH PANDEMI COVID-19
}

\author{
Suci Lestari \\ SMAN 4 Kabupaten Tangerang \\ sucilestari88888@gmail.com
}

\begin{abstract}
Abstrak
Situasi pandemi pada saat ini menyebabkan beberapa perubahan yang merubah tatanan hidup, termasuk di bidang pendidikan. Sehingga semua tingkat pendidikan "dipaksa" beralih untuk beradaptasi dengan drastis dalam melaksanakan pembelajaran bahasa inggris di rumah melalui media online. Penelitian ini bertujuan untuk menjabarkan secara teoritis dengan menggunakan kajian kepustakaan terkait pembelajaran online berbasis proyek pada pembelajaran bahasa inggris di era pandemi Covid-19 yang berdampak pada sistem belajar dari rumah. Sistem pembelajaran online berbasis proyek pelajar diberikan keleluasaan untuk mengakses materi pembelajaran bahasa inggris melalui internet. Pendidik dan peserta didik dapat mengakses banyak platform maupun media online melalui jaringan internet. Beberapa hal yang menjadi kendala dalam penerapan pembelajaran online antara lain terbatasnya kuota internet, dan pendidik serta peserta didik yang tidak terbiasa dengan penerapan pembelajaran online.

Kata kunci: Pembelajaran Online, Pembelajaran Bahasa Inggris, Pembelajaran Berbasis Proyek, pandemi Covid-19
\end{abstract}

\begin{abstract}
The current pandemic situation caused several changes that change the order of life, including in the field of education. So that all levels of education are "forced" to shift to adapt drastically in carrying out English language learning at home through online media. This study aims to describe theoretically using a literature review related to project-based online learning in English language learning in the Covid-19 pandemic era which has an impact on the learning system from home. Project-based online learning system allows students to access English learning materials via the internet. Educators and students can access many platforms and online media through the internet. Some things that become obstacles in the implementation of online learning include limited internet quota, and educators and students who are not familiar with the implementation of online learning.
\end{abstract}

Keyword: Online Learning, Project-Based, english language Learning, pancemic Covid-19

\section{PENDAHULUAN}

Situasi pandemi covid-19 membuat kesulitan diberbagai aspek terutama pada aspek pendidikan. Kesulitan yang terjadi yaitu menciptakan proses pembelajaran yang kondusif antara guru dengan siswa. Sehingga mengalami kesulitan dalam memberikan motivasi belajar kepada siswa agar pembelajaran tetap berjalan sebagaimana mestinya sesuai tujuan pembelajaran. Situasi tersebut mendorong para guru untuk menggunakan metodemetode pembelajaran yang menarik terhadap pembelajaran mata pelajaran Bahasa Inggris di SMAN 4 Kota Tagerang agar dapat memotivasi siswa untuk belajar sesuai tujuan pembelajaran dengan menggunakan media yang tepat.

Mempelajari Bahasa Inggris bukan perihal yang mudah. Banyak siswa yang mengalami kesulitan untuk memahami pengetahuan Bahasa Inggris. Karena banyak yang harus dipelajari tidak hanya belajar kosa kata saja melainkan harus bisa menggunakan kata Bahasa Inggris dalam kehidupan sehari-hari sebagai alat komunikasi dan belajar Bahasa Inggris baik verbal atau grammar. Untuk meningkatkan motivasi siswa terhadap belajar Bahasa Inggris di saat pandemi Covid-19 guru harus lebih kreatif dalam memilih media yang menarik sehingga proses pembelajaran berjalan dengan sesuai tujuan pembelajaran. Proses 
pembelajaran yang digunakan harus lebih efektif seperti pembelajaran melalui online.

Media pembelajaran tidak bisa dipisahkan terhadap teknologi informasi dan komunikasi di situasi pandemi Covid19. Keuntungan yang dirasakan dapat memecahkan masalah-masalah pembelajaran karena pada saat ini sulitnya waktu pertemuan tatap muka dan memberikan sumber materi yang dicetak kepada siswa secara langsung dan mampu mengatasi hambatan, dan pertemuan jarak jauh antara guru dengan siswa.

Menurut Uwes A. Chaeruman (2008: 26), mengemukakan bahwa pembelajaran dengan menggunakan TIK dikenal dengan sebutan $e$ - learning. E-learning merupakan sebuah proses pembelajaran yang berbasis elektronik menggunakan jaringan komputer, web dan jaringan internet. Pembelajaran online adalah model pembelajaran jarak jauh dengan menggunakan TIK, seperti Internet, CDROOM (Molinda, 2005). Sistem pembelajaran awalnya berdasarkan tatap muka dikelas, dan mungkin bisa diubah dengan sistem pembelajaran yang terintegrasi melalui Internet atau online learning. Pembelajaran online learning menghubungkan siswa dengan guru yang secara fisik terpisah bahkan berjarak tetapi bisa menjalin komunikasi, dan interaksi.

$$
\text { E-learning memiliki tiga }
$$

kemungkinan dalam pengembangan pembelajaran berbasis internet yaitu Web Course, Web Centric Course, dan Web Enhaceed Course (Prayito, 2010). Sistem pembelajaran E-learning lebih mudah untuk belajar di mana saja, meningkatkan kemandirian dalam belajar pada siswa, dan membuat suasana lebih aktif dalam belajar (Tigowati, Efendi, \& Budiyanto, 2017).

Menurut Yaniawati (2013), terdapat beberapa tahapan klasifikasi penggunaan teknologi komunikasi dan informasi dalam pembelajaran E-learning: (1) Emerging adalah tahap awal untuk menyadari pentingnya teknologi untuk pembelajaran. (2) Applying adalah pengaplikasian dari teknologi sebagai objek untuk dipelajari. (3) Integrating, pengintegrasian ke dalam kurikulum. (4) Transforming, ini adalah tahap paling ideal karena teknologi informasi telah menjadi katalis untuk pengembangan pendidikan

Pembelajaran online tidak akan berfungsi jika tidak adanya sinergi antara strategi yang tepat dengan metode pembelajaran yang sesuai. Aplikasi yang dapat mengintegrasikan pembelajaran online adalah pembelajaran berbasis proyek. Bagian terpenting dari pembelajaran berbasis proyek mengajukan pertanyaan atau masalah yang disajikan untuk mengumpulkan dan memulai kegiatan yang menyoroti sejumlah proyek, hingga suatu produk diperoleh sebagai serangkaian kegiatan komunikasi individu atau hasil dari berbagai tugas yang menjawab pertanyaan. Dengan demikian, pembelajaran berbasis proyek ini menawarkan siswa kesempatan untuk belajar konsep yang mendalam dan juga secara mandiri meningkatkan hasil belajar siswa.

Menurut Sucilestari dan Arizona (2018), berpendapat bahwa pembelajaran berbasis proyek adalah penelitian mendalam tentang topik dunia nyata. Jadi, proyek yang dibuat oleh siswa tergantung pada pengamatan tentang masalah dunia nyata di sekitar mereka yang akan memberi mereka makna.

Pembelajaran berbasis proyek sangat tepat digunakan sebagai metode pembelajaran Bahasa Inggris di SMAN 4 Kabupaten Tagerang. Kesulitan yang dihadapi oleh guru ketika mengajar Bahasa Inggris dapat teratasi. Siswa akan lebih mudah memahami pembelajaran walaupun lewat media Online.

Sehingga menciptakan kebutuhan pembelajaran yang efektif diterapkan pada siswa untuk meningkatkan kompetensi para siswa. Selain itu, karena dampak pandemi Covid-19, yang menyebabkan pembelajaran gagal karena mereka harus tinggal di rumah dan menerapkan physical distancing, pembelajaran online berbasis proyek adalah jalan keluar untuk menjawab permasalah ini.

\section{METODE PENELITIAN}

Metode yang digunakan dalam penelitian adalah studi literatur sekunder 
dengan mengumpulkan data-data berdasarkan hasil penelitian para sumber. Metode penelitian adalah sebuah cara prosedural untuk mengerjakan sesuatu dengan sebuah sistem yang teratur dan terencana. mencapai suatu tujuan secara efektif dan efisien (M. Dien Madjid, 2014:217) dan (A. Daliman, 2015:27).

Data-data yang digunakan disini untuk mengumpulkan suatu data ialah berbentuk data yang berjenis sekunder, berdasarkan pada berbagai macam pencarian-pencarian yang didapat dari berbagai macam artikel jurnal. Tidak hanya itu, pengertian yang didapatkan juga bersumber dari berbagai perpustakaanperpustakaan dan sumber-sumber dari situs pembelajaran online mengenai pembelajaran online berbasis proyek ( Zed, 2014).

Dalam riset pada pustaka telah menjelaskan bahwasannya penelusuran pustaka itu tidak hanya diperuntukan pada langkah-langkah yang terdapat diawal yang bertujuan dalam mempersiapkan kerangka dalam penelitian akan tetapi pada saat yang sama juga ketika digunakan dalam sumber perpustakaan jika ingin mendapatkan sebuah data bersifat investigasi. Ketika kita mendapatkan data tersebut, maka data itu akan jelas di kumpulkan juga di kompilasi kemudian ditinjau setelahnya di analisa dan yang terakhir akan disimpulkan dengan tujuan untuk dijadikan rekomendasi pada sebuah pembelajaran Bahasa Inggris di SMA yang bersifat literatur.

\section{HASIL DAN PEMBAHASAN}

\section{Perubahan Kegiatan Pembelajaran di Tengah Pandemi Covid-19}

Pembelajaran jarak jauh saat ini menjadi pilihan utama untuk melakukan kegiatan belajar mengajar secara online di tengah pandemi Covid-19 yang sedang melanda. Situasi pandemi Covid-19 menyebabkan perubahan yang luar biasa, termasuk di bidang pendidikan. Seolaholah semua tingkat pendidikan "dipaksa" beralih untuk beradaptasi dengan drastis dalam melaksanakan pembelajaran di rumah melalui media online. Masalah dalam dunia pendidikan terletak pada kenyataan bahwa proses pembelajaran tidak seragam, baik dalam standar atau kualitas yang diperlukan untuk hasil pembelajaran. Pendidik harus memastikan bahwa kegiatan belajar mengajar berlanjut, bahkan ketika siswa di rumah. Solusi untuk menghadapi permasalahan tersebut yang harus dilakukan oleh guru yaitu merancang media pembelajaran yang tepat sebagai inovasi melalui penggunaan media online.

Sistem pembelajaran ini di implementasikan menggunakan komputer atau laptop yang terhubung ke dalam jaringan internet. Sehingga guru dapat belajar bersama pada saat yang sama melalui grup media sosial seperti WhatsApp (WA), Telegram, Instagram, aplikasi Zoom atau Google Meet. Dengan cara ini, guru dapat memastikan bahwa siswa berpartisipasi dalam pembelajaran secara bersamaan, bahkan di tempat yang berbeda. Guru juga dapat memberikan tugas yang terukur sesuai dengan tujuan materi yang diberikan kepada siswa.

Situasi ini membuat guru dan siswa merasa terbebani. Khususnya untuk para siswa, mereka dituntut untuk kreatif dalam menyampaikan materi melalui metode pembelajaran online. Situasi tersebut dibutuhkan penyesuaian ditingkat pendidikan dalam kebutuhan pembelajaran. Efeknya akan menyebabkan stres fisik dan psikis (mental). Pola pikir positif dapat membantu menerapkan media pembelajaran online yang tepat, sehingga menghasilkan belajar yang berkualitas. Ketika belajar di rumah menggunakan media online diharapkan orang tua bisa menjadi role model dalam membantu anak-anak belajar, dan menghadapi perubahan dalam situasi ini. Peran orangtua sangat penting ketika proses pembelajaran berlangsung.

Guru bukan satu-satunya penentu dalam situasi ini peran orang tua membawa pengaruh berjalan pembelajaran online dengan baik atau tidak. Tidak sedikit orang tua mengeluh tentang sarana pembelajaran jarak jauh melalui internet (online). Khususnya untuk orang tua yang work from home (WFH), mereka harus terus 
menemani anak-anak mereka, terutama anak-anak yang masih berusia dini. Mengingat teknologi yang belum merata dalam penggunaan media pembelajaran, seperti laptop, gadget, dan lainnya.

\section{Pembelajaran Online (E-Learning)}

Pembelajaran online merupakan pembelajaran yang menggunakan teknologi informasi dan komunikasi (TIK) yang memungkinkan siswa dapat belajar kapan saja, dimana saja (Dahiya, 2012).

Ada tiga hal yang berpengaruh dalam kegiatan e-learning, yaitu: (1) Kegiatan pembelajaran yang dilakukan dalam penggunaan jaringan, dan terbatas pada penggunaan internet. (2) Mendukung layanan pembelajaran yang diterima oleh siswa. (3) Ketersediaan layanan dukungan tutor yang dapat membantu siswa belajar jika mereka mengalami kesulitan.

E-learning memiliki banyak manfaat didunia pendidikan khususnya pada masa pandemi Covid-19 seperti saat ini, yaitu: (1) Memiliki fleksibilitas terhadap ruang dan waktu, jadi pada pembelajaran yang bersifat tradisional, siswa dan guru diharuskan untuk hadir dikelas pada jamjam yang sudah dijadwalkan, berbeda dengan e-learning, yang mana memberikan fleksibilitas untuk menentukan atau memilih waktu dan tempat dalam mengakses pelajaran, (2) Pembelajaran yang bersifat mandiri, pembelajaran online atau e-learning memberikan keleluasaan kepada peserta didik untuk mengatur pembelajaran mereka, dimana peserta didik diberi kebebasan dalam memutuskan kapan akan memulai, kapan harus menyelesaikan, dan bagian- bagian mana dari modul atau materi yang ingin mereka pelajari terlebih dahulu, (3) Menghemat biaya, biaya yang dapat dihemat antara lain biaya transportasi atau kost selama masa belajar, biaya manajemen administrasi, penyediaan fasilitas fisik dan fasilitas belajar, (4) Memiliki fleksibilitas kecepatan belajar, pembelajaran online atau e-learning dapat menyesuaikan kecepatan belajar pada masing-masing peserta didik, (5) Memiliki standarisasi pengajaran, pembelajaran online atau e-learning akan selalu memiliki kualitas yang sama setiap kali diakses dan tidak tergantung pada suasana hati pengajar, (6) Memiliki efektifitas pengajaran, dimana selama pembelajaran online atau e-learning ini pengajar dapat memberikan pelajaran dalam bentuk simulasi dan situasi, dengan menggunakan sebuah permainan dan animasi, (7) Kecepatan distribusi, elearning dapat dengan cepat mencapai semua arah, (8) Ketersediaan pembelajaran sesuai permintaan, e-learning dapat diakses kapan saja, (9) Mengotomatiskan proses administrasi, e-learning menggunakan Learning Management System (LMS) yang berfungsi sebagai program atau rencana untuk pelajaran $e$ learning. LMS memiliki fungsi sebagai alat penyimpanan data peserta didik, pelajaran, dan proses pembelajaran yang telah terjadi.

Pembelajaran online dapat dilaksanakan dengan cara-cara berikut, yaitu: (1) Proses pembelajaran tradisional (lebih banyak pertemuan tatap muka) dengan pembelajaran tambahan melalui media online interaktif komputer atau dengan menggunakan grafik komputer interaktif. (2) Menggunakan metode campuran, yang berarti bahwa sebagian besar proses pembelajaran berlangsung melalui komputer, tetapi juga masih membutuhkan tatap muka untuk untuk kepentingan tutorial atau diskusi tentang materi pendidikan. (3) Seluruh metode pembelajaran hanya dilakukan secara online, dan metode ini tidak pernah melakukan tatap muka. Dengan menggunakan model ini, komunikasi antara peserta didik dan staf pengajar dilakukan secara simultan atau individual dengan didukung jaringan komputer.

Terdapat beberapa hambatan pada proses pembelajaran online yaitu mengakses internet karena tidak semua kondisi perekonomian memungkinkan untuk membeli paket internet bagi siswa maupun guru. Selain itu, belum terbiasanya menggunakan beberapa aplikasi sebagai penunjang pembelajaran antara siswa dan guru. Masalah akses ke internet dan jaringan jelas menjadi perhatian utama bagi semua pihak. 
Langkah ini merupakan aspek konkret yang harus diikuti dalam menyediakan fasilitas internet oleh semua pihak. Agar pembelajaran online bisa berjalan dengan baik diiringi dengan media yang tepat dalam proses pembelajaran. Guru harus mempertimbangkan dalam pemilihan pembelajaran online yang tepat. Terdapat beberapa pembelajaran online seperti pembelajaran berbasis proyek.

\section{Pembelajaran Berbasis Proyek}

Pendekatan pembelajaran yang sesuai dengan situasi saat ini yang dapat meningkatkan kemampuan siswa dalam pembelajaran online yaitu penggunaan Pembelajaran berbasis proyek. Pembelajaran berbasis proyek digunakan sebagai cara atau metode di dalam proses pembelajaran untuk memperoleh kemampuan atau kecakapan sikap, pengetahuan, dan keterampilan.

Fokus dari pembelajaran ini merupakan aktivitas atau kegiatan para siswa yang mampu menghasilkan produk melalui penerapan keterampilan penelitian dan analisis untuk membuat dan memberikan produk pendidikan berdasarkan kegiatan pembelajaran secara online bersama guru. Produk yang dihasilkan dari pembelajaran berbasis proyek yaitu dalam bentuk barang, desain, skema, karya tulis, karya seni, teknologi/kerajinan dan video. Dengan menerapkan pembelajaran berbasis proyek, siswa dapat mempraktikkan perencanaan dan melaksanakan kegiatan sesuai dengan rencana dan melaporkan hasil kegiatan pembelajaran kepada guru.

Seperti yang dilakukan oleh guru mata pelajaran Bahasa Inggris di SMAN 4 Kabupaten Tagerang menggunakan pembelajaran berbasis proyek sangat tepat digunakan karena mengasah kreativitas pada siswa, meningkatkan kemandirian pada siswa, meningkatkan daya fikir pada siswa, dan siswa dapat bertanggung jawab terhadap pembelajaran yang diajarkan oleh guru dalam bentuk hasil seperti produk dalam bentuk video, pamplet animasi, dan maping map yang berkaitan dengan mata pelajaran yang diajarkan oleh guru bahasa Inggris.
Bentuk kegiatan proyek terdiri atas (1) Proyek produksi yang melibatkan penciptaan, seperti selebaran, video, program radio, poster, laporan tertulis, artikel, foto, pesan, panduan, manual, daftar makanan, jadwal perjalanan, dll; (2) Proyek kinerja seperti pertunjukan, pertunjukan lisan, pertunjukan teater, pertunjukan makanan atau peragaan busana; (3) Proyek organisasi seperti pembentukan klub, kelompok diskusi atau program mitra diskusi.

Menurut Fried- Booth (2002), menyatakan bahwa ada dua jenis proyek, yaitu (1) Proyek kecil atau sederhana yang hanya membutuhkan dua atau tiga pertemuan. Proyek ini hanya dilaksanakan di ruang kelas. (2) Proyek ukuran penuh yang membutuhkan kegiatan kompleks di luar ruang kelas harus diselesaikan dalam jangka waktu yang lebih lama.

Setiap siswa memiliki cara belajar yang berbeda-beda agar proses pembelajaran bisa dipahami oleh setiap siswa. Pembelajaran berbasis proyek ini sangat efektif digunakan dalam situasi saat ini. Karena dapat membantu siswa dalam menjalankan berbagai kegiatan belajar yang diberikan oleh guru dapat mengetahui apakah pembelajaran berjalan dengan baik atau tidak. Penggunaan Pembelajaran berbasis proyek ini memberikan siswa sebuah kesempatan untuk mengeksplorasi konten (bahan) menggunakan metode atau cara yang bermakna bagi diri mereka sendiri dan untuk melakukan percobaan bersama.

Pembelajaran berbasis proyek merupakan investigasi atau penelitian yang mendalam tentang topik nyata dan sangat membantu minat dan upaya ketika siswa sedang mendapatkan pembelajaran dari guru. Sinergi Pembelajaran Online Berbasis Proyek sebagai solusi yang tepat digunakan di tengah pandemi Covid-19.

Menurut Noor et al. (2017), menyatakan bahwa e-learning dalam pembelajaran berbasis proyek sangat efektif digunakan untuk mencapai kinerja spiritual, sosial, proyek, produk dan penyelesaian belajar pada siswa. Berdasarkan hasil penelitian yang dijelaskan di atas, pembelajaran online 
berbasis proyek dapat menjadi solusi untuk mendukung pembelajaran selama pandemi Covid-19 di tingkat sekolah SMA. Pembelajaran online berbasis proyek memungkinkan siswa untuk lebih maju secara bermakna, mandiri, kreatif, sehingga pengetahuan dan keterampilan yang mereka dapatkan dijadikan bekal mereka untuk menjadi pemecah masalah dari masalah yang mereka hadapi.

\section{SIMPULAN}

Pembelajaran online ditengah pandemi covid-19 menuntut setiap guru untuk berfikir lebih kreatif dalam menentukan pembelajaran yang tepat. Pembelajaran online sangat tepat digunakan didalam situasi saat ini. Pembelajaran online bisa digunakan dimana saja namun setiap solusi pasti selalu ada dampak. Pembelajaran online membutuhkan jaringan internet sedangkan tidak setiap siswa atau guru memiliki jaringan tersebut.

Pembelajaran e-learning sangat membantu proses pembelajaran berjalan dengan baik. Guru dapat menyampaikan tugasnya kepada siswa di tengah pandemi covid-19 ini. Setiap pembelajaran tersampaikan dengan lancar kepada siswa. Setiap guru harus berfikir kreatif dalam menentukan cara pembelajaran yang tepat. Sehingga pembelajaran dapat tersampaikan dan siswa dapat mendapatkan pengalaman belajarnya.

Pembelajaran bahasa inggris berbasis proyek sangat efektif digunakan sebagai pembelajaran kepada siswa. Pembelajaran berbasis proyek ini digunakan sebagai

\section{DAFTAR PUSTAKA}

A, Daliman. 2015. Metode Penelitian Sejarah. Yogyakarta: Ombak.

Dahiya, S., Jaggi, S., Chaturvedi, K.K., Bhardwaj, A., Goyal, R.C. and Varghese, C. 2016. An eLearning System for Agricultural Education. Indian Research Journal of Extension Education, 12(3), pp.132-135

Fried-Booth, D. L. 2002. Introduction, Resource Book for Teachers: Project Work. Oxford: Oxford University Press. metode dalam proses pembelajaran bahasa inggris untuk mencapai kompetensi sikap, pengetahuan dan keterampilan yang disusun dalam tujuan mata pelajaran. Kegiatan yang dilakukan oleh siswa ketika menggunakan pembelajaran berbasis proyek yaitu fokus pada kegiatan siswa untuk menghasilkan produk dengan meningkatkan kreativitas, melatih kemandirian siswa, berfikir kritis dalam menganalisis suatu permasalahan dan menghasilkan produk yang berorientasi pada materi yang telah disusun. Seperti membuat video animasi, video dokumenter, pamplet, maping map dan pementasan seni teater.

Melalui penerapan pembelajaran bahasa inggris berbasis proyek siswa terlatih untuk belajar secara mandiri mulai dari merencanakan, menyusun hingga melaporkan hasil kegiatan yang diperoleh oleh siswa. Pembelajaran berbasis proyek ini mengakomodir kemampuan belajar siswa yang heterogen baik dalam cara dan gaya belajar siswa untuk mengeksplorasi dan kemampuan berbahasa inggris dari kemampuan menulis, membaca, mendengar dan berbicara

Pembelajaran bahasa inggris berbasis proyek ini sangat efektif digunakan dalam situasi saat ini, karena dapat membantu siswa dalam proses memahami pembelajaran yang diberikan oleh guru. Implementasi metode ini juga dapat diukur keberhasilanya dengan indicator produk yang dihasilkan oleh siswa. sehingga pembelajaran daring berbasis project ini dapat meningkatkan kompetensi siswa dalam pembelajaran bahasa inggris

Madjid. M Dien. 2014. Ilmu Sejarah Sebuah Pengantar. Jakarta:Kencana.

Molinda, M. 2005. Instructional Technology and Media for Learning. New Jersey : Colombus, Ohio.

Noor, ME., Hardyanto, W \& Wibawanto, H. 2017. Penggunaan E-Learning dalam Pembelajaran Berbasis Proyek di SMA Negeri 1 Jepara. Innovative Journal of Curriculum and Educational Technology 6 (1), 17-26.

Prayito. 2010. Matematika Humanistik Berbasis Konstruktivisme Berbantuan 
E- Learning Materi. Pendidikan ELearning, (2), 1-9.

Sucilestari, R. \& Arizona, K. 2018. Peningkatan Kecakapan Hidup melalui Pembelajaran Sains Berbasis Proyek. Prosiding Seminar Nasional Pendidikan Biologi. 436441.

Sari, P. 2015. Memotivasi Belajar Dengan Menggunakan E-Learning. Jurnal Ummul Qura, 6 (2).

Setyosari, P. 2007. Pembelajaran Sistem Online: Tantangan dan Rangsangan. Majalah Ilmiah Pembelajaran 2, 110.

Sucilestari, R. \& Arizona, K. 2018. Peningkatan Kecakapan Hidup melalui Pembelajaran Sains Berbasis Proyek. Prosiding Seminar
Nasional Pendidikan Biologi. 436441.

Tigowati, T., Efendi, A., \& Budiyanto, C. W. 2017. The Influence of E-learning Use to Student Cognitive Performance and Motivation in Digital Simulation Course. IJIE (Indonesian Journal of Informatics Education), 1(1), 127.

Uwes A. Chaeruman. 2008. Mendorong penerapan e-learning di sekolah. Jurnal Teknodik, 12 (1), 26-32.

Yaniawati, R. P. 2013. Pengaruh ELearning Untuk Meningkatkan Daya Matematik Mahasiswa. Jurnal Cakrawala Pendidikan, (3), 381-393.

Zed, M. 2014. Metode Penelitian Kepustakaan. Jakarta: Yayasan Obor Indonesia. 